\title{
Potret Pekerja Kerajinan Seni Ukir Relief Jepara
}

\author{
Alamsyah \\ Program Studi Ilmu Sejarah, Faultas Ilmu Budaya, Universitas Diponegoro Semarang \\ Email: alam_mahir@yahoo.com
}

\begin{abstract}
The existence of relief carvings in Jepara is marked by the presence of white coral ornaments found in the Mantingan Mosque. These ornaments show that the craft of relief carving has been around for hundreds of years in Jepara. The existence and development of relief carvings are thanks to the contributions of workers or relief engravers. With the ability to carve it out, they can preserve and develop this craft. Most of the relief carving skills were obtained from the apprenticeship process from the carver that had been around his house since he was in elementary school. A sculptor needs a long process to become a relief engraver because of not all engravers can be relief engravers. The ability of the relief engraver was getting better after the establishment of the Technical School in the 1930s. Relief engravers who get a formal education will be able to integrate self-taught and theoretical abilities. The development of relief carving art grew rapidly during the independence period, the new order, and the reform order. Relief engravers need high carving abilities and complicated technical abilities so they can carve a fragment of a story or theme and have a naturalist pattern. At the beginning of the 21st century, the number of relief engravers was fewer and dominated by the older generation because the younger generation was reluctant to learn carving. Although relief engravers are increasingly scarce, their skills have not been rewarded with high wages.
\end{abstract}

Keywords: Portrait, Worker, Carving Art, Relief, Jepara

\section{Pendahuluan}

Kabupaten Jepara terletak di pantai utara Jawa Tengah. Wilayah ini sejak abad ke-16 sudah terbiasa melakukan perdaganan lokal, interinsuler, dan internasional. Kabupaten ini terkenal dengan industri ukir baik di tingkat lokal maupun dunia (Fauziyah, dkk, 2014: 21). Keberadaan kerajinan ukir Jepara dapat dilacak dari adanya seni ukir relief yang terbuat dari batu karang putih yang bentuknya bundar, bujur sangkar, persegi panjang dengan kedua sisinya berbentuk garis kurawal (Alamsyah, 2017: 9981; Pujianto, dkk, 1999: 6-7). Ragam hias yang diperkenalkan mencerminkan pengaruh seni ukir klasik, Hindu, Tiongkok, dan Arab tercermin dalam relief Ramayana, hiasan medallion dan mega mendung, serta geometris atau slimpetan. Motif relief tersebut adalah tumbuh-tumbuhan, bunga teratai, dan hewan yang distilirkan (disamarkan) (Hayati, 2004: 87; Maziyah, dkk, 2015: 74-75; Marizar, 2012: 81-86). Ornamen tersebut terkesan hanya merupakan pemandangan alam atau hiasan tumbuh-tumbuhan, namun dari jarak yang agak berjauhan nampak hiasan berbentuk hewan menyembul di tengah-tengahnya (Hartojo dan Budiman, 1982: 46). Dalam perkembangannya, ragam hias dan motif hias kerajinan ukir mendapatkan pengaruh ragam hias Padjadjaran, ragam hias berbagai daerah, Mataram Islam, Kolonial (Eropa), dan ragam 
hias modern (Kadir, 1980, 15-21; Priyanto, 2018: 98). Pada akhir abad ke-20 hingga awal abad k-21, kehidupan masyarakat Jepara masih banyak ditopang oleh industri kerajinan ukir kayu dengan berbagai dinamikanya (Alamsyah, 2017: 9981).

Tentu saja perkembangan seni ukir relief di Jepara tidak dapat dilepaskan dari peran pekerja (pengukir) relief. Dari tangan trampil pengukir, berbagai bentuk dan motif relief dapat terwujud. Relief Jepara sebagai produk seni ukir telah tersebar di berbagai daerah dan dunia. Oleh karena itu artikel ini akan memotret eksistensi pengukir relief. Merekalah yang melestarikan keberadaan seni ukir relief di Jepara.

\section{Metode}

Metode penelitian dilakukan dalam upaya menemukan dan mengumpulkan sumber atau informasi (heuristik) baik sumber primer maupun sekunder. Sumber primer diperoleh dari hasil wawancara terhadap para pekerja atau pengukir relief yang terdapat di Desa Mulyoharjo Kecamatan Kota Jepara dan Desa Senenan Kecamatan Tahunan Jepara (Garraghan, 1947: 34; Gottschalk, 1975: 32; Herlina, 2008: 17-24). Wawancara dilakukan untuk mendapatkan informasi dengan cara bertanya langsung kepada responden terhadap pendapat, sikap, dan pengalaman pribadi berkaitan dengan kegiatannya sekaligus menemukan masalah dan mengetahui hal-hal yang lebih mendalam tentang pekerja relief (Saebani, tt: 191; Singarimbun, dkk, 1995: 193; Basuki, 2006: 173). Metode wawancara juga menggunakan metode analisis life history untuk memperoleh pandangan dari dalam dan data pengalaman individu untuk mendapatkan gambaran yang lebih mendalam mengenai detail dari individu pekerja relief (Bungin, 2004: 66-67). Sumber primer juga diperoleh dari observasi atau pengamatan langsung terhadap produk-produk relief yang dibuat oleh pekerja. Adapun sumber sekunder diperoleh dari pustaka, jurnal, dan sumber yang lain (Garraghan, 1947: 34; Gottschalk, 1975: 32; Herlina, 2008: 17-24). Setelah data terkumpul, tahap selanjutnya adalah kritik dan interpretasi terhadap sumber. Setelah dilakukan kritik dan interpretasi, data diklasifikasi, dihubung-hubungkan atau diakumulasikan antara data satu dengan yang lainnya, sebagai suatu bentuk interpretasi dan sintesa dalam rangka mererekonstruksi menjadi sebuah artikel.

\section{Hasil dan Diskusi}

\subsection{Eksistensi Relief di Jepara}

Relief sebagai salah satu produk ukir Jepara merupakan pahatan yang menampilkan perbedaan bentuk dan gambar dari permukaan rata di sekitarnya (Mendiknas, 2008: 1159). Seni ukir relief Jepara mulai berkembang sejak berdirinya Openbare Ambactsschool, sekolah pertukangan yang kemudian menjadi Sekolah Teknik. Di sekolah ini para calon pengukir belajar mengembangkan ketrampilan dan kreativitas. Seni ukir relief pada masa ini kebanyakan masih berbentuk relief rendah, yaitu kedalaman ukirannya kurang dari setengah dari objek yang digambarkan. Penggambaran objek cenderung bergaya dekoratif, temanya menampilkan cerita wayang. Seni ukir relief tahun 1959 mulai dikembangkan dengan banyak gaya seperti realis atau naturalis antara lain perjalanan Hayam Wuruk dan Joko Tarub. Perkembangan pesat seni ukir relief terjadi pada tahun 1974 dengan banyaknya karya-karya yang dihasilkan pengukir. Karya-karya ukir relief yang muncul adalah Gerobag Sapi, Sunan Kalijogo, Srikandi Belajar Memanah, Jamu Gendong, dan Pasar Tradisonal (Priyanto, 2013: 168-174; Kadir, 1979: 55). Pada awal abad ke-21 ini, motif ukir relief semakin beragam. 
Ukiran relief memiliki 5 (lima) kriteria yaitu jenis ukiran tinggi, teknik pembuaannya rumit atau ngrawit., menggambarkan sebuah fragmen cerita atau tema, bercorak naturalis, dan produknya otonomo. Ukiran tinggi maksudnya adalah jalinan bentuk antara objek satu dengan objek yang lainnya muncul dalam psosisi tinggi rendah, naik turun, timbul tenggelam atau tumpang tindih bersap-sap. Ukiran ini mampu menggambarkan bentuk 3 (tiga) dimensi. Maksud dari ngrawit adalah seni menghasilkan karya ukiran yang ngrawit atau sangat rumit dan harus dikerjakan dengan penuh etelitian, sabar dan hati-hati. Adapun ukiran tematik maksudnya adalah relief ini menggambarkan sebuah tema kehidupan tertentu. Ukiran naturalis adalah objek yang digambarkan dalam relief banyak ditampilkan dalam corak naturalsitik, objek yang ada dalam dunia nyata. Ukirannya otonom maksudnya adalah relief tidak harus melekat pada perabot seperti almari dan sebagainya. Relief ini dapat berdiri sendiri tanpa terkait media tertentu (Haryadi, 2016: 10-16).

\subsection{Potret Pengukir Relief Jepara}

\section{a. Curiculum Vitae Pengrajin}

Curiculum vitae atau riwayat hidup pekerja (pengukir) seni ukir relief berasal dari 2 (dua) pusat kerajinan ukir relief di Jepara yaitu di Desa Mulyoharjo Kecamatan Kota Jepara dan Desa Senenan Kecamatan Tahunan. Pada awalnya mereka hanya belajar mengukir motifmotif sederhana berupa daun-daunan. Proses belajar pengukir dimulai sejak masa kanakkanak, ketika masih bersekolah di Sekolah Dasar. Umur pengukir relief pada tahun 2018 ini antara 40 tahun hingga 63 tahun. Ada beberapa alasan mengapa mereka sejak kecil tertarik sebagai pengukir, pertama latar belakang keluarga yang kurang sejahtera dengan mata pencaharian sebagai nelayan atau buruh tani. Orang tua menyarankan anaknya belajar mengukir agar tidak miskin seperti orang tuanya. Ada persepsi pada tahun 1970-an, bahwa pengukir kehidupannya lebih baik dari pada nelayan atau buruh tani. Kedua, Orang tuanya menjadi tukang kayu atau pengukir sehingga anaknya diarahkan berlatih mengukir. Ketiga, lingkungan di desa tersebut banyak yang bermata pencaharian sebagai pengukir, sehingga banyak tempat yang digunakan untuk melakukan magang. Dalam proses magang ini mereka tidak digaji (Wawancara dengan Supardi Oktober 2018; Partono Oktober 2018; Dardi Juli 2018; Partono Oktober 2018; Hendriyanto Oktober 2018; Rodhi Juli 2018; Sukoco Oktober, dan wawancara dengan Slamet Juli 2018). Latar belakang orang tua pengukir relief ada yang bermata pencaharian sebagai petani (Supardi), nelayan (Sukoco), sebagai finishing mebel (Partono), dan tukang kayu (Hendriyono).

Pada tahun 1970-an, anak-anak belajar mengukir setelah pulang sekolah dan mereka memandang bahwa belajar mengukir sebagai sarana mengisi waktu luang (Wawancara dengan Partono Oktober 2018). Setelah pulang sekolah pada pukul 10 atau 11 siang, mereka istirahat sebentar dan mulai belajar mengukir pada pukul 13.00 hingga pukul 16.30 (Wawancara dengan Supardi Oktober 2018; Alamsyah dan Laksono, 2017: 7157)). Menurut mereka, belajar mengukir tidak mengganggu kegiatan sekolah karena dilakukan setelah pulang dari sekolah, dan malam harinya bisa tetap belajar (Wawancara dengan Partono Oktober 2018). Pada awalnya, setelah belajar mengukir selama 1 (satu) tahun hingga 2 (dua) tahun, mereka baru dapat mengukir produk yang sederhana yaitu motif daun-daunan 2 (dua) dimensi pada kursi, meja, almari, dan produk yang lain. Para pekerja relief saat ini sebagian besar hanya lulusan sekolah dasar. 


\section{b. Proses Soft Skill Pengukir}

Proses belajar mengukir menggunakan alat ukir dengan pola yang bebas. Bahan kayu yang akan diukir adalah kayu sisa bekas yang tidak terpakai (Wawancara dengan Dardi, Juli 2018). Ukiran pertama yang dipelajarinya adalah motif daun-daunan. Motif tersebut merupakan motif dasar yang dipraktekkan para pengukir pemula. Motif daun-daunan digunakan karena sederhana dan tidak terlalu rumit. Dengan motif sederhana tersebut, pengukir pemula dapat melatih keterampilan tangannya agar memes dalam menatah (Wawancara dengan Sukoco, Oktober 2018). Setelah anak-anak belajar mengukir selama 1 (satu) hingga 2 dua) tahun, mereka menguasai beberapa motif sederhana. Beberapa kesulitan yang dialami pada proses belajar berkaitan dengan cara memegang alat, mengasah pahat, membuat gambar pola, dan menghafal alat. Setelah bisa mengukirpun, tidak semua pengukir dapat membuat gambar pola (Wawancara dengan Partono, Oktober 2018; Sukoco, Oktober 2018). Untuk mendapatkan kemahiran diperlukan waktu yang lama. Kemampuan mengukir tingkat lanjut diperoleh setelah bekerja sebagai pengukir dalam waktu yang lama. Pekerjaan tersebut dilakukan di tempat juragan atau bisa juga dibawa pulang. Produk yang dibuat diantaranya bagian ukiran dari kursi, meja, dan produk lain yang tidak begitu sulit. Pada tahapan berikutnya, setelah mulai menguasai berbagai jenis motif ukir, mereka dapat menerima pesanan untuk motif Majapahit, Jepara, Cirebon, dan motif yang lain (Alamsyah dan Laksono, 2017; 7157).

Pasca lulus Sekolah Dasar, ada juga pengukir selain bekerja juga melanjutkan ke Sekolah Teknik Jurusan Ukir. Di sekolah tingkat pertama ini, mereka mempelajari berbagai motif ukir, mulai dari motif Majapahit, Padjadjaran, Jawa, dan motif yang lain. Dari berbagai motif tersebut, motif Majapahit merupakan motif yang rumit dan pengerjaannya harus teliti (Wawancara dengan Supardi, Oktober 2018). Ketika sudah mampu dan dipercaya senior, barulah mereka dilepas untuk membuat ukiran. Kemudian mulai menggunakan pola sesuai gambar. Bila pengukir yunior mengalami kesulitan, maka pengukir senior akan mengarahkan dan memperbaiki hasil ukirannya (wawancara dengan Dardi, Juli 2018).

Ketika proses belajar dan awal bekerja, bila ada seseorang mengalami kesulitan membuat relief maka mereka dapat bertanya kepada pengukir yang lebih senior, terutama bila mengukir objekuntuk diarahkan. Bila dalam proses belajar dan bekerja, pengukir memiliki ketekunan dan totalitas maka akan cepat mahir dan kemampuan mengukirnyapun akan semakin baik. Untuk mempercepat kemampuan mengukir, seringkali pada periode tahun 1990-an mereka merantau ke berbagai daerah (Gustami, 1999: 254).

\subsection{Proses Pembuatan Produk Relief}

\section{a. Proses Pembuatan}

Mengukir relief lebih sulit dibanding mengukir bukan relief. Pengukir relief membutuhkan proses belajar dan pengalaman mengukir dalam waktu yang lama. Para pengukir pemula hanya dapat mengukir ragam hias sederhana seperti ragam hias Majapahit, Mataram, dan lain sebagainya. Setelah mengukir dalam waktu yang lama sekitar 5 sampai dengan 10 tahun dan hasil ukirannya bagus, mereka mulai dapat belajar mengukir relief. Pengukir relief membutuhkan ketekunan, ketelitian, dan sangat detail. Setiap pengukir relief mempunyai keahlian berbeda. Ada pengukir yang hanya dapat mengukir background dari sebuah ukiran relief. Misalnya ketika membuat ukiran relief cerita Ramayana, pengukir hanya mampu membuat background tumbuhan, tidak mahir dalam membuat ukiran manusia, binatang maupun ukiran tiga dimensi. Ukiran relief lebih sulit karena bentuk ukirannya 3 
(tiga) dimensi dan hasil ukirannya terlihat lebih hidup. Adapun ukiran di luar relief adalah jenis ukiran 2 (dua) dimensi saja (Wawancara dengan Joko, Juli 2016).

Proses pembuatan seni ukir relief sebagian besar dilakukan oleh pengukir berdasarkan permintaan konsumen. Tahapan pembuatannya dimulai dari pertama, tersedianya kayu jati dalam bentuk papan yang ukurannya dibuat sesuai keinginan. Kedua, membuat gambar atau sketsa di triplek sesuai ukuran pesanan. Dalam menggambar di triplek memerlukan beberapa tahapan diantaranya gambar pada triplek dibuat dengan kapur. Kapur digunakan karena mudah dihapus apa bila tidak sesuai dengan keinginan. Proses penggambaran ini dapat berlangsung hingga dua minggu, tergantung tingkat kerumitan sebuah gambar dan ukuran. Setelah gambar kapur selesai, pembuat gambar bermusyawarah dengan pekerja lainnya. Bila gambar kurang sempurna maka dilakukan perbaikan. Bila gambar sudah baik, maka gambar kapur ditebalkan dengan menggunakan pensil. Tahapan selanjutnya, gambar dipertegas dengan menggunakan spidol. Gambar yang sudah jadi kemudian disalin pada sebuah kertas dengan cara "dijiplak". Triplek yang sudah bergambar ditempelkan kertas. Bayangan garis gambar akan terlihat pada kertas, dan kemudian pembuat gambar tinggal mengikuti bayangan tersebut hingga menjadi sebuah gambar. Dari kertas tersebut gambar dipindahkan ke media ukir dengan cara dibledoki terlebih dahulu. Gambar asli pada triplek tidak langsung dibuang, karena digunakan sebagai panduan ketika gambar pada media ukir sudah hilang (Wawancara Sukoco:2018). Produk relief memerlukan waktu yang panjang dalam pembuatannya. Ada yang membutuhkan waktu beberapa minggu, ada yang beberapa bulan, bahkan ada yang beberapa tahun tergantung tingkat kerumitan dan besar kecilnya ukuran seni ukir relief (Wawancara dengan Sukoco, Oktober 2018).

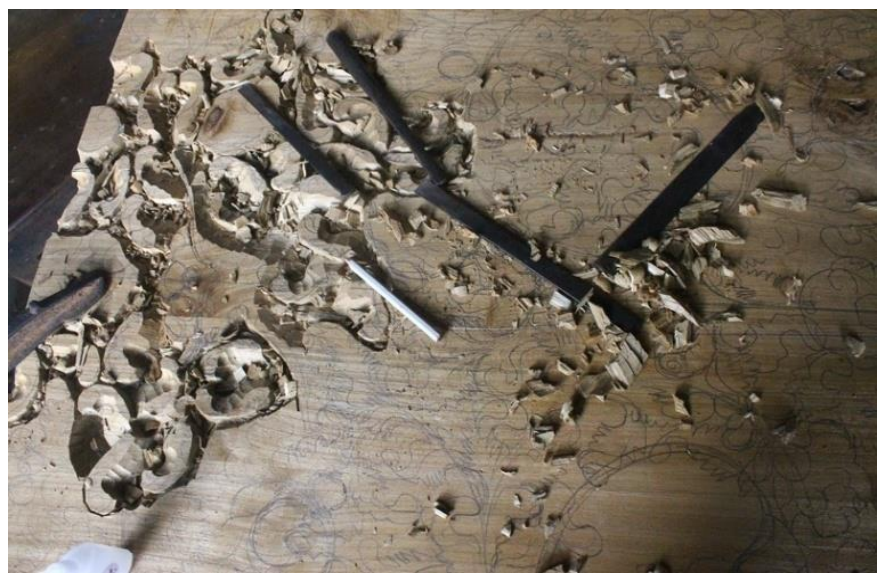

Gambar 1: Proses Bledoki yang Berfungsi untuk mengikat pola pada Media Kayu Sumber: Dokumentasi Peneliti, Oktober 2018

Selain membuat rancangan pada triplek, ada pula gambar yang langsung dibuat pada papan kayu. Papan kayu digambar dengan pensil dan spidol. Setelah itu kayu dibentuk mengikuti gambar, dan gambar akan hilang. Bentuk awal merupakan kunci keberhasilan pembuatan ukir relief. Bentuk awal yang bagus akan menentukan bentuk akhir yang dibuat (Wawancara dengan Hendriyanto, Oktober 2018). 


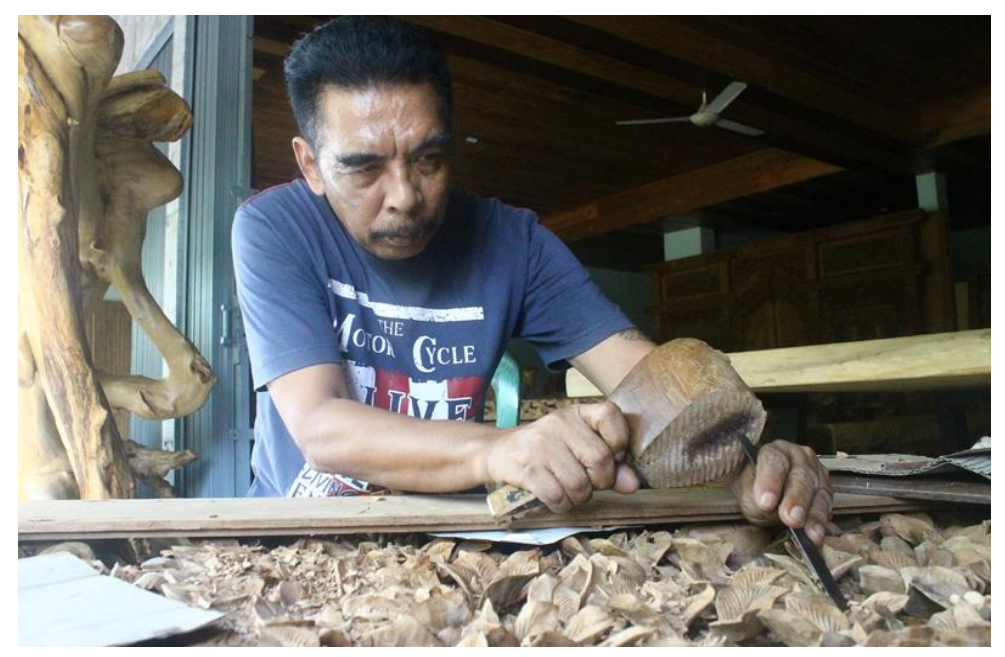

Gambar 2. Hendriyanto Melakukan Proses Mengukir Relief Sumber. Dokumentasi Peneliti, Oktober 2018

Proses produksi ukir relief berbeda dengan produk ukir lainnya, dibawah ini di jelaskan tahapan membuat sebuah ukir relief. Sebagai contoh, relief dengan tema "Alam Pedesaan" ukuran 1 meter x 3 meter dengaan tebal papan 8 sentimeter, maka tahapan yang dilakukan adalah: Pertama, menyiapkan bahan baku kayu jati usia di atas 10 tahun karena semakin tua kualitas kayu maka ukirannya akan lebih bagus. Kayu yang mudah diukir adalah kayu yang besar dan memiliki umur yang sudah tua. Kayu yang sudah tua lebih empuk, seratnya lebih bagus, sehinga mudah diukir dan tidak menguras tenaga (Wawancara dengan Hendriyanto Oktober 2018). Kedua, kayu dikeringkan dengan kadar air dibawah $15 \%$ supaya kayu tahan lama dan tidak terserang bubuk kayu atau hama lainnya. Ketiga, Kayu dibuat papan sesuai ukuran, untuk ukuran diameter lebih dari 30 centimeter dibuat dengan menggabungkan beberapa papan kayu jati sehingga membentuk bidang datar yang dinginkan, kemudian disambung dengan lem dan bagian pinggirnya dipaku. Keempat, ketebalan papan tergantung tema reliefnya, jika motifnya kompleks maka semakin tebal ukuran papannya. Kelima, setelah bahan baku siap, cerita relief digambar sesuai tema dengan menggunakan spidol atau pensil. Proses menggambar dimulai dari urutan ceritanya dan background cerita yang semuanya ditampilkan dengan detail. Keenam, tahap selanjutnya diukir secara kasar dengan cara membuat dasaran. Jika dasarannya telah selasai maka ornamenn lainnya dapat diselesaikan. Ketujuh, ukiran relief dengan ukuran di atas membutuhkan pengerjaan sekitar 4 bulan dengan jumlah pengukir 2-3 orang. Masing-masing pengukir memiliki tugas yang berbeda sesuai keahliannya. Dalam mengukir relief, yang tersulit adalah bagaimana membuat ukiran terlihat hidup dan tidak kaku. Oleh karena itu, setiap tim pengukir relief terdapat 1 (satu) orang ketua yang tugasnya mengawasi hasil ukiran apakah sudah sesuai atau belum.

Setelah selesai diukir, relief dibingkai. Ukiran relief yang sudah jadi tidak perlu diamplas karena jika diamplas, unsur reliefnya akan hilang dan tidak terlihat hidup. Relief juga tidak perlu dicat atau finishing karena yang ditonjolkan selain ukirannya juga unsur kayu jati yang menampilkan guratan khas sehingga menambah nilai seninya. Namun demikian, ada juga ukir relief yang di finishing atau dicat sesuai permintaan konsumen. 


\section{b. Peralatan Mengukir Relief}

Para pengukir menggunakan alat untuk mengukir yang dikenal dengan nama tatah. Alat ini terbuat dari besi pipih dan melengkung, dimana pada salah satu sisi ujungnya telah diasah hingga tajam agar dapat membuat ukiran pada kayu. Satu set tatah berisi 30 buah, terdiri dari penilat, penuku, kol, dan coret. Penilat terbuat dari besi dengan salah satu sisi ujungnya tajam dan bentuknya rata. Penilat digunakan untuk membentuk ukiran dengan tekstur yang rata. Berbentuk lurus, untuk membuat atau memahat berbentuk rata dan lurus. Ukuran penilat antara $0,5 \mathrm{~cm}-6 \mathrm{~cm}$. Penuku berbentuk hampir sama dengan penilat, namun pada bagian matanya yang tajam berbentuk sedikit melengkung menyerupai kuku. Penuku digunakan untuk membuat ukiran yang agak melengkung untuk membentuk tekstur bergelombang atau bengkok, seperti pembuatan daun-kelopak bunga dan lain sebagainya. Ukuran penuku antara $2 \mathrm{~cm}-6 \mathrm{~cm}$. Adapun $\mathrm{Kol}$ berbentuk lempengan memanjang dan melengkung hampir menyerupai pipa yang dibelah dua. Kol juga sering disebut kol suruh yang digunakan untuk membentuk gelombang atau lubang pada kayu. Fungsi kol seperti penuku namun lebih cepat hasilnya. Ukuran $\mathrm{kol}$ antara 0,5 cm $-6 \mathrm{~cm}$ (Wawancara dengan Dardi, Juli 2018; Soepratno, 2004: 29-30). Coret ini diperkenalkan sekitar tahun 1983 oleh orang Jepang yang gunanya untuk membentuk tekstur bergaris seperti rambut manusia.

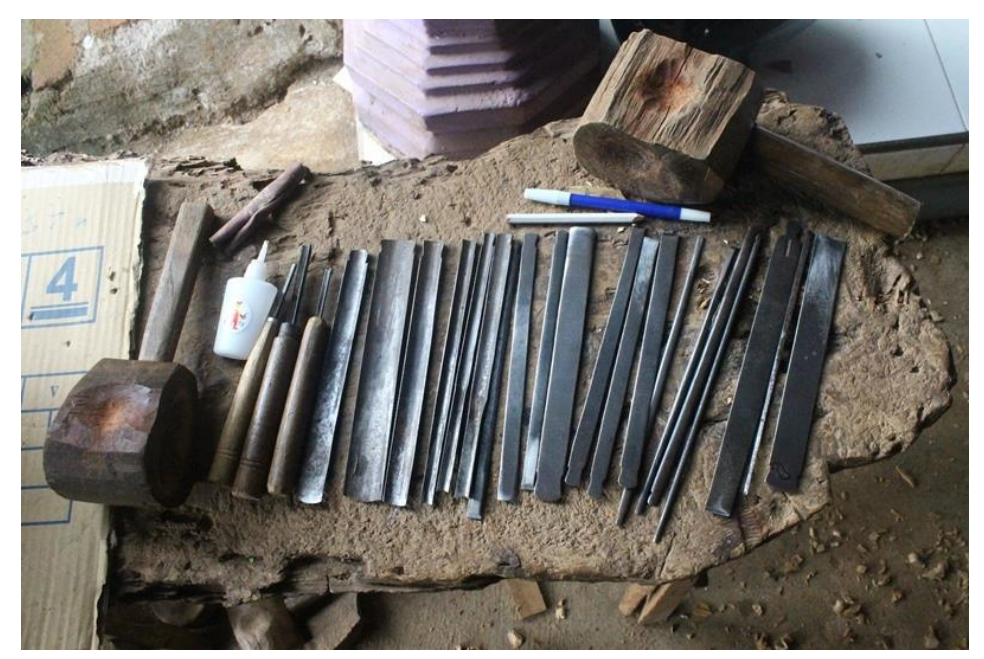

Gambar 3: Seperangkat alat tatah terdiri dari Penilat, Penguku, Kol, Coret, dan Palu Sumber. Dokumentasi Peneliti, Oktober 2018

Selain di atas, alat ukir yang lain adalah Palu atau martil dari kayu (ganden) yang terbuat dari kayu sawo yang berkarakter keras, batu asah (ungkal), sikat ijuk untuk menghilangkan bekas pahatan pada ukiran, dan tanggem atau pres supaya kayu tidak bergeser saat diukir (FEDEP, tt: 1-2). Satu set alat tatah dengan kualitas bagus harganya sekitar 1 juta hingga 1.5 juta rupiah, sedangkan harga palu atau ganden sekitar 15 ribu rupiah. Adapun alat untuk menggambar motif ukir relief diantaranya kertas gambar, pensil $\mathrm{H}, \mathrm{HB}$ atau B, karet penghapus, jangka, penggaris lurus, dan pengagris segitiga (Soepratno, 2004: 29-30). 


\subsection{Produk Relief}

Karya ukiran relief yang dibuat oleh pengukir merupakan karya yang rumit dan membutuhkan keahlian mengukir tingkat tinggi dan proses yang panjang. Pekerja tidak seluruhnya dapat menguasai pembuatan setiap bagian relief. Pengukir yang baru menguasai ukiran background dalam setiap tema, akan bekerja sama dengan pengukir lainnya yang lebih ahli dalam mengukir jalan ceritanya seperti ukiran manusia, hewan, atau yang memiliki tingkat kesulitan lebih tinggi. Para pengukir relief menghasilkan berbagai motif sesuai dengan permintaan konsumen. Secara umum, motif relief yang dibuat pengukir dikelompokkan berdasarkan tema cerita. Ada relief yang bercerita tentang panorama alam pedesaan, cerita pewayangan, relief flora fauna, dan lain-lain. Sebelum tahun 1990-an, ukir relief belum banyak diminati seperti saat ini. Pengukir mengerjakan ukiran relief yang diaplikasikan pada meja atau kursi. Seiring berjalannya waktu ukiran relief banyak dijadikan hiasan dinding dan ceritanya pun lebih beragam (Wawancara dengan Supardi, Oktober 2018; Partono Oktober 2018; Dardi Juli 2018; Partono Oktober 2018; Hendriyanto Oktober 2018; Rodhi Juli 2018; Sukoco Oktober, dan wawancara dengan Slamet Juli 2018). Berikut uraian setiap tema cerita dalam ukir relief.

Pertama, Relief Panorama Alam Pedesaan. Relief ini biasanya menceritakan kehidupan atau suasana pedesaan, pemandangan alam seperti gunung, sungai, sawah, ternak, rumah, petani yang membajak sawah, pepohonan, suasana pasar, dan lain sebagainya. Relief pedesaan bercerita tentang suasana alam dan kehidupan rakyat di pedesaan, seperti aktivitas dan tradisi masyarakat khas pedesaan tempo dulu seperti pasar, pertanian tradisional, gerobag sapi (cikar), sabung ayam, bakul jamu gendong, penjual sate, dan sebagainya (Haryadi, 2016: 53; Gustami, 1999: 236).

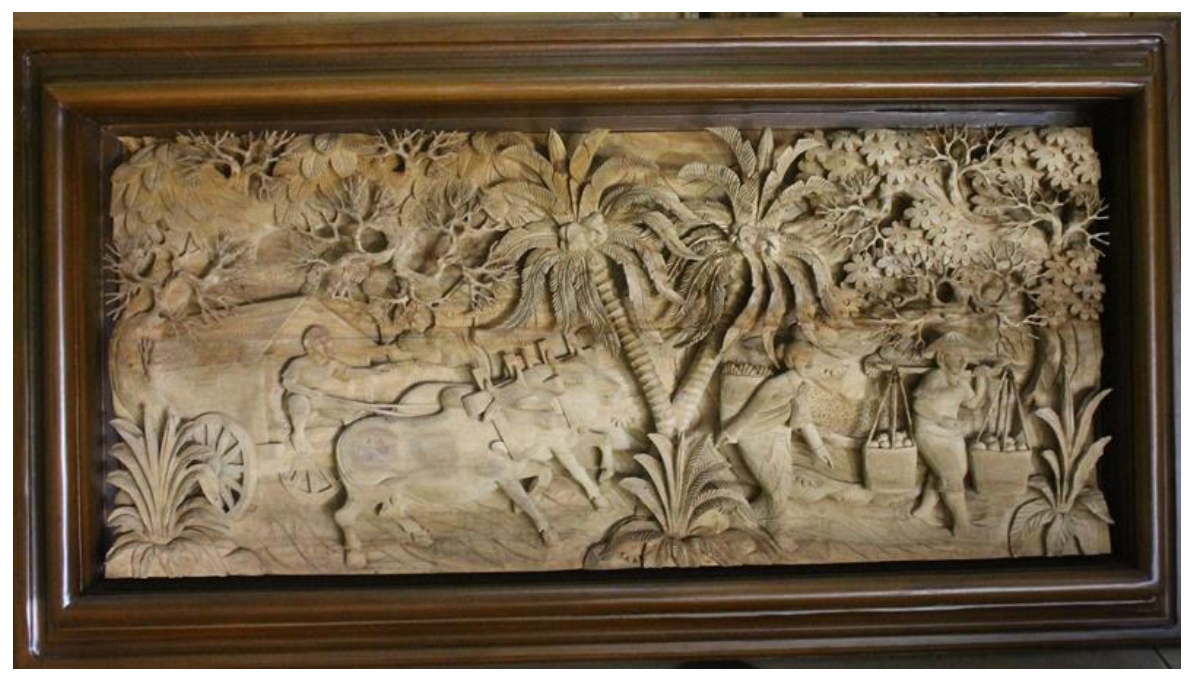

Gambar 4. Relief Pedesaan

Sumber. Dokumentasi Peneliti Oktober 2018

Kedua, Relief Cerita Pewayangan. Relief pewayangan merupakan salah satu tema relief tradisional Jepara yang sudah ada sejak awal kemunculan. Pada awal perkembangannya, ukiran relief perwayangan yang dibuat adalah ukiran wayang kulit dan 
wayang orang. Pada akhir abad ke-20 dan awal abad ke-21, ukiran relief menceritakan tentang kisah pewayangan (Haryadi: 2016: 55)

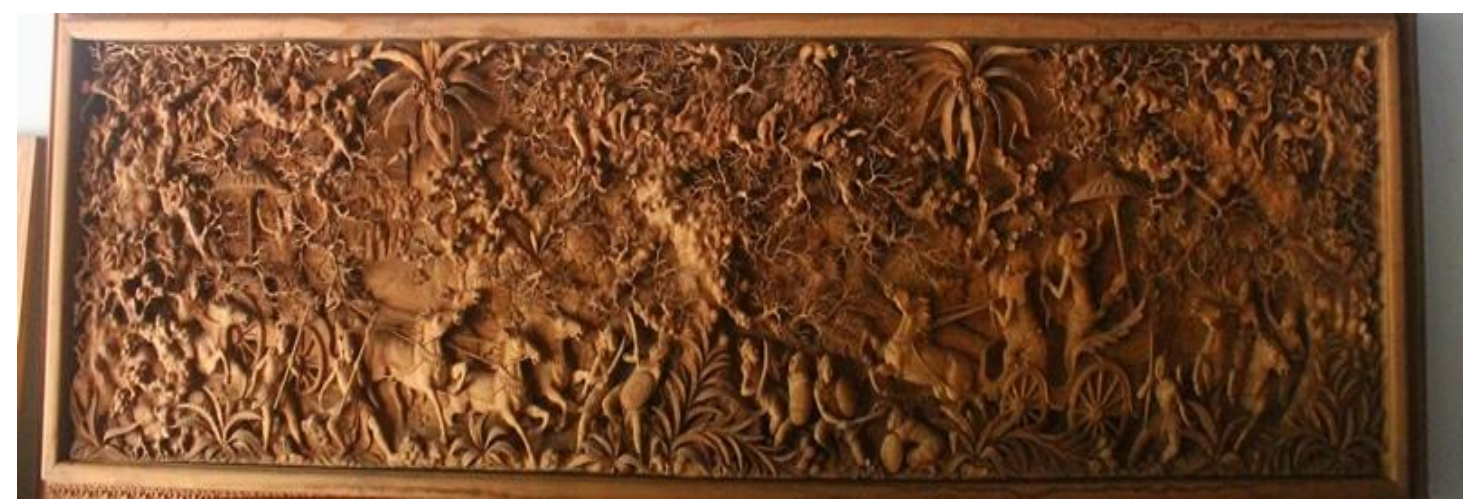

Gambar 5:. Relief Karno Tanding, merupakan penggalan dari kisah pewayangan Sumber. Dokumentasi Peneliti, Oktober 2018

Sebuah ukiran relief pewayangan dapat bersumber dari kisah yang sama namun fragmen yang ditampilkan dan cara penyajiannya sering berbeda tergantung dari kreativitas pereliefnya (Haryadi, 2016: 56). Seni ukir relief bertema perwayangan menampilkan fragmen kisah Ramayana, Mahbarata. Relief cerita pewayangan sering ditampilkan secara sinoptik, karena dalam satu relief terdapat beberapa adegan untuk mengilustrasikan sebuah alur cerita dan disertai deskripsi singkat cerita yang ditampilkan. Relief seni ukir pewayangan ada juga yang bertema Kijang Kencana dalam kisah Ramayana (Haryadi, 2016: 56; Gustami, 1999: 236).

Ketiga, Relief flora-fauna. Ukiran relief ini menampilkan tema kehidupan berbagai hewan dan tumbuh-tumbuhan, baik hewan darat, air dan udara. Flora fauna darat yang digambarkan biasanya berupa pepohonan atau hutan khas tropis beserta hewan didalamnya yang terdiri dari keluarga mamalia, unggas, burung, dan reptil. Sedangkan di dalam air dapat digambarkan berbagai jenis ikan dan hewan air termasuk terumbu karang dan kehidupan bawah laut yang eksotik (Haryadi, 2016: 27).

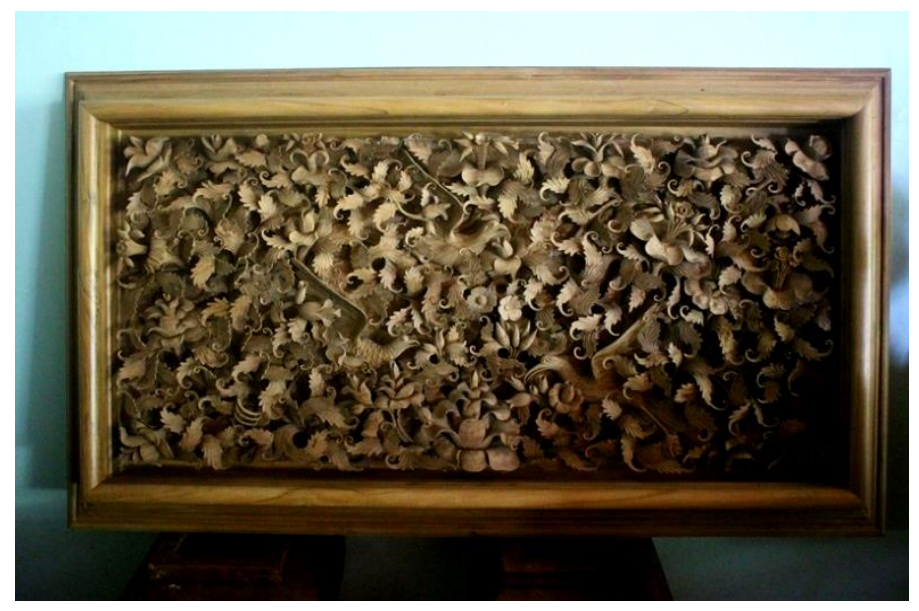

Gambar 6: Burung dan Dedaunan

Sumber. Dokumentasi Peneliti, Oktober 2018 
Keempat, Relief Religi. Biasanya menggambarkan aktifvitas agama tertentu, contohnya relief perjamuan makan kristiani dan lain sebagainya. Selain itu ada pula relif relief mahluk mitologi dalam agama tionghoa.

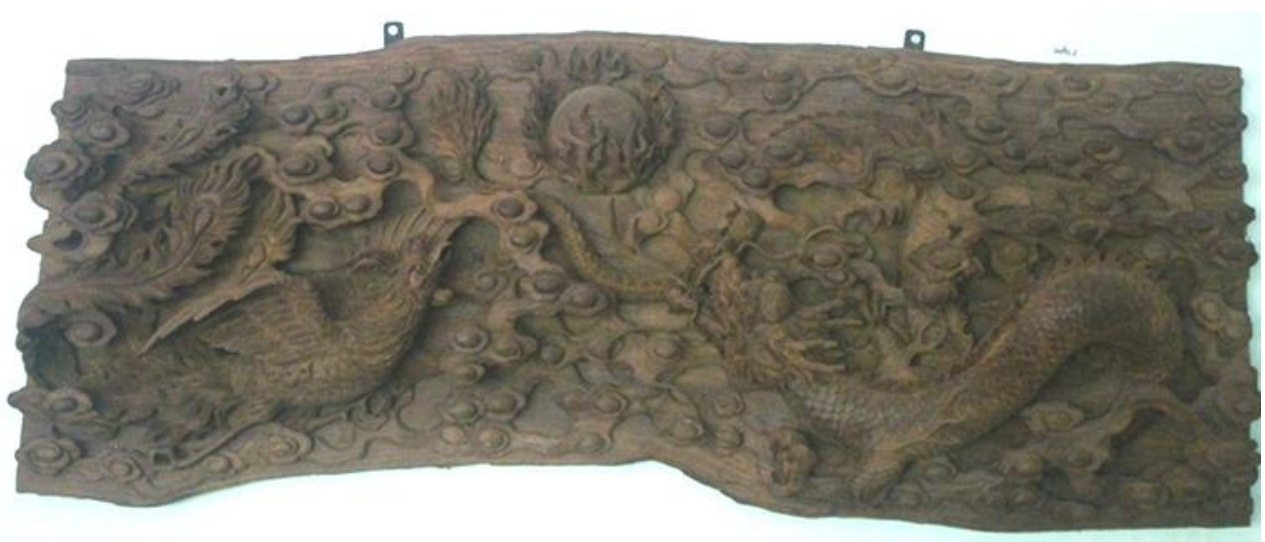

Gambar 7: Relief Burung Phonix, Bola Api, dan Naga

Sumber. Dokumentasi Peneliti, Oktober 2018

\subsection{Upah, Perekonomian, dan Hubungan Sosial Pengukir}

\section{a. Sistem Pengupahan}

Di Jepara terdapat dua sistem pengupahan untuk para pekerja ukiran relief. Juragan atau bos yang memberi pekerjaan dengan upah sistem harian maupun borongan. Kedua sistem tersebut merupakan hasil kesepakatan dari kedua belah pihak antara bos dan pekerja.

\section{1) Sistem Harian}

Sistem harian biasanya memiliki jam kerja yang pasti yaitu masuk jam 8 pagi dan pulang jam 4 sore dengan istirahat satu jam saat dhuhur antara jam 12.00 sampai jam 13.00. Namun demikian aturan jam kerjanya belum seketat seperti di pabrik. Masih ada toleransi karena biasanya pekerja masih ada ikatan saudara atau tetangga. Para pekerja ukiran relief bebas bekerja dimanapun, termasuk di luar kota. Pada 1970-an para pekerja ukir Jepara banyak yang bekerja pada perusahaan atau pada seorang bos di luar kota. Para pekerja ukir diberi upah dengan sistem upah harian. Pada 1973, di Semarang, upah harian yang diterima pekerja ukir sekitar Rp.250,-. Bila bekerja lembur sampai jam 9 malam dapat memperoleh upah sekitar Rp.500,- seharinya (Wawancara dengan Hendriyono, Oktober 2018). Pada 1979 upah harian juga masih sekitar Rp.250,-. Para pekerja biasanya juga diberikan makan ketika bekerja.

Pada 1984, pekerja ukir Jepara yang merantau ke Surabaya memperoleh upah sebesar Rp.1.500,- perhari. Di Semarang, saat bekerja pada perusahan untuk membuat produk relief berukuran kecil upah yang diterima sekitar Rp. 7.500,-. Pada 1980-an, Pekerja ukir di Jepara mendapatan upah perhari sekitar Rp.4.000,-. Adapun upah perhari membuat ukiran relief di Jakarta sekitar Rp.8.000,- dengan waktu kerja 8 jam sehari. Bila pekerja mengambil lembur hingga jam 12 malam, maka akan mendapatkan uang sembur sebesar 1 hari kerja (Wawancara dengan Dardi, Juli 2018; Sukoco, Oktober 2018). 
Pada tahun 2000-an, upah perhari yang diterima pekerja sekitar Rp.70.000,-. Di Jawa Timur, upah pekerja ukiran relief per hari pada tahun 2013 sekitar Rp. 100.000,-. Adapun upah pekerja ukiran relief di Jepara pada 2018 dengan tingkat kemahiran tinggi sekitar Rp.150.000,-, sedangkan upah pekerja ukiran relief perhari dengan keahlian biasa sekitar Rp.75.000,-. Penentuan upah harian pada tahun 2018 berdasarkan tingkat keahlian mengukir dan ditentukan oleh ketua kelompok (Wawancara dengan Dardi, Juli 2018).

Sistem harian umumnya untuk pesanan dalam jumlah banyak dan perlu diselesaikan dalam waktu yang cepat. Sebuah pesanan yang dikerjakan dengan sistem harian biasanya dikerjakan oleh 3 orang hingga 4 orang. Namun demikian, hasil ukiran relief yang dikerjakan oleh banyak orang dengan sistem harian apalagi terburu-buru hasilnya tidak maksimal. Menurut pekerja, sistem harian lebih mengikat karena pekerja tidak leluasa meninggalkan pekerjaan di jam kerja (Wawancara dengan Hendriyanto Oktober 2018).

\section{2) Sistem borongan}

Sistem borongan tidak memiliki waktu kerja pokok, karena pekerjaan dilakukan sesuai dengan kesepakatan antara bos dan pekerjanya. Kesepakatan itu meliputi upah yang diberikan sesuai keahlian dan target waktu penyelesaian sebuah produk ukiran relief. Penghitungan upah pekerja borongan dilakukan dengan menggunakan ukuran kayu yang dikerjakan. Umumnya upah borongan dihitung perdesimeter atau tiap $10 \mathrm{~cm}$. Namun ada pula yang memakai harga keseluruhan. Istilah borongan itu lahir pada tahun 1970-an, karena pada saat itu pesanan dikerjakan bersama atau bareng dengan teman-teman di rumah. Pada tahun 1970an, pekerja dengan sistem borongan dapat memperoleh upah perhari sekitar Rp.1.000Rp.1.500,-.untuk sebuah produk ukir yang dikerjakan. Umumnya ukiran digunakan pada pintu lemari atau bangku. Satu pesanan borongan dapat diselesaikan dalam waktu seminggu (Wawancara dengan Dardi, Juli 2018).

Dalam sistem borongaan, pekerja boleh mengambil uang makan dari bos. Seminggu sekali, pada hari Kamis sore, pekerja biasanya meminjam uang atau ngebon. Uang ini nantinya akan dipotong dari upah total setelah pekerjaan selesai. Sistem borongan memungkinkan para pekerja menyesuaikan waktu untuk keperluan lainnya. Ada sistem borongan dimana pekerjaannya boleh dibawa pulang, dan ada pula yang harus dikerjakan di tempat si bos. Pekerjaan yang tidak boleh dibawa pulang karena si bos ingin mengawasi proses ukir. Hal ini wajar karena ukiran relief lebih komplek dan harus teliti dalam setiap detilnya. Selain itu, satu produk relief dikerjakan oleh lebih dari satu pekerja, masing-masing pengukir relief memiliki kelebihan dan keahlian yang berbeda-beda. Ada yang mahir membuat objek, ada yang hanya dapat membuat background, dan lain sebagainya (Wawancara dengan Joko, Oktober 2016).

Upah borongan dalam ukiran relief tergantung ukuran relief yang dikerjakan. Miaslnya relief untuk hiasan dinding dengan cerita "Alam Pedesaan" dengan ukuran 2 x 1 meter maka upahnya dihitung setiap Desimeter. Upahnya per desimeter sekitar 40 ribu hingga 50 ribu. Biasanya ukiran relief dengan ukuran tersebut dikerjakan sekitar 1-2 bulan tergantung cerita dan motif yang digunakan. Pendapatan pekerja tergantung pada rajin tidaknya pekerja. Besaran upah berdasarkan produk yang dikerjakan. Dalam sistem borongan, pekerja biasanya memperoleh bingkisan hari raya berupa sarung, baju, dan uang. Meskipun pesanan ukiran relief sedikit, upah pekerja tetap sama dan tidak dikurangi, bahkan cenderung bertambah untuk menyesuaikan harga kebutuhan pokok (Wawancara dengan Partono, Oktober 2018).

Pekerja ukiran relief tidak memiliki ikatan dengan bosnya, sehingga pekerja bisa mengambil pekerjaan dari bos yang lain. Hal itu terjadi karena ukiran relief merupakan sebuah karya seni yang dibuat dengan perasaan. Adanya ikatan dikhawatirkan akan 
mengganggu perasaan dari si pekerja sehingga dapat berdampak pada karya ukiran relief yang dibuat oleh pekerja menjadi tidak maksimal (Wawancara dengan Sukoco, Oktober 2018).

\section{b. Kehidupan Ekonomi dan hubungan Sosial}

Upah yang diterima oleh pengukir relief, bagi pekerja yang lajang digunakan untuk membantu orang tua dan untuk membeli makanan kecil. Pada 1975, upah hasil mengukir relief dapat memenuhi kebutuhan gaya hidup, termasuk membeli pakaian untuk penampilan. Pekerja ukir pada era tersebut memiliki ciri khas yaitu menggunakan celana jeans dan kaus oblong. Celana jeans bermerk Levis dan Lea menjadi favorit anak ukir karena terkesan santai. Ketika belum menikah dan bekerja di Semarang sebagai pengukir, dengan penampilannya tersebut banyak disenangi oleh wanita (Wawancara dengan Hendriyanto Oktober 2018). Pada 1991, ketika sudah memiliki anak, bila telah menyelesaikan sebuah pekerjaan upah sebagian dibelikan emas. Pada tahun 1990-an, upah yang diterima dapat digunakan untuk memenuhi kebutuhan pokok, menabung uang untuk menikah, membangun rumah, membeli tanah, motor, dan menyekolahkan anaknya.

Pada 2018, upah yang diperoleh pekerja sekitar 70 ribu hingga 150 ribu rupiah. Upah yang diterima tersebut tidak sebanding dengan biaya kebutuhan yang semakin meningkat. Upah terkesan tidak memiliki "aji”, dan hanya dapat digunakan untuk memenuhi kebutuhan harian saja. Oleh sebab itu generasi muda sekarang lebih tertarik bekerja di pabrik, meskipun upah sebagai pengukir dan buruh pabrik tidak banyak berbeda. Namun mereka senang sebagai pengukir karena bekerja di tempat yang adem, dapat ngobrol dengan teman, dan melakukan aktivias lainnya (Wawancara dengan Partono, Oktober 2018; Hendriyanto, Oktober 2018).

Dari aspek relasi sosial, diantara para pekerja ukiran relief di Jepara memiliki hubungan kekeluargaan yang baik. Para pekerja ukiran relief ketika muda sering merantau dan bekerja di luar kota seperti Semarang, Surabaya, dan Jakarta. Dari pekerjaannya sebagai pengukir tersebut, mereka menikah dan membentuk sebuah keluarga. Dari sisi sosial, sistem pengupahan berpengaruh pada hungunan sosial pekerja. Sistem upah harian membuat pekerja harus menyesuaikan waktu dalam berhubungan dengan keluarga. Adapun untuk sisitem upah borongan, para pekerja lebih fleksibel dalam pekerja dan dalam berhubungan dengan keluarganya. Sistem borongan memperbolehkan pekerja membawa ukiran yang sedang dikerjakannya ke rumahnya sehingga dapat mengerjakan pekerjaan rumah yang lain. Namun ada juga pengukir yang tidak dapat membawa pulang pekerjaannya karena ukurannya yang besar maupun karena dilarang oleh bos. Meskipun demikian, mereka tetap dapat mengerjakan pekerjaan lainya (Wawancara dengan Supardi, Oktober 2018; Partono, Oktober 2018; Dardi Juli 2018; Partono Oktober 2018; Hendriyanto Oktober 2018; Rodhi Juli 2018; Sukoco Oktober, dan wawancara dengan Slamet Juli 2018).

Baik pekerja upah harian maupun upah bulanan, mereka tetap berinteraksi sosial secara baik. Ketika ada tetangga atau saudara yang menyelenggarakan hajatan, pekerja tetap meluangkan waktu untuk datang. Mereka datang pada acara hajatan setelah jam kerjanya. Adapun untuk pekerja borongan, dapat dengan bebas menentukan waktu, karena tidak adanya kewajiban memenuhi jam kerja. 


\section{Simpulan}

Pekerja ukiran relief merupakan salah satu pelestari seni ukir Jepara. Mereka mempelajari seni ukir sejak kecil hingga bertahan sebagai pengukir relief saat ini (2018). Mereka dengan tekun mempelajari teknik-teknik mengukir, mulai dari teknik dasar hingga menjadi pengukir relief tingkat mahir atau profesional. Dalam mengembangkan keahliannya, para pengukir ini ada yang tetap bekerja di Jepara, namun banyak yang merantau ke luar daerah. Sejak 1975-an, banyak pekerja yang membuat ukiran relief ke Jakarta, Surabaya, Semarang dengan upah yang bervariasi. Pada periode 1970-an hingga awal tahuun 2000-an, pekerjaan sebagai pengukir relief cukup menjanjikan. Melalui hasil mengukir relief mereka dapat menikah, memiliki rumah, motor, dan dapat menyekolahkan anak-anaknya. Pada periode 2018, potret kehidupan pengukir relief tercermin dari upah yang diterima antara 75 ribu hingga 150 ribu tergantung keahliannya. Dengan upah tersebut dipandang belum sebanding dengan keahlian profesional yang dimiliki di tengah keterbatasan sumber daya manusia pengukir relief. Saat ini mayoritas yang bekerja sebagai pengukir relief umurnya di atas 50 tahun, dan generasi muda sudah tidak ada yang tertarik lagi sebagai pengukir relief.

\section{Daftar Pustaka}

Alamsyah and Arido Laksono, "Woman "Carver": Between Domestic Work and Fulfilling Economic Needs at Indonesian Carving Craft Center in the Early 21st Century". Advanced Science Letters Vol. 23, No. 8., 2017. Pp. 7157

Alamsyah. "The Ups and Downs of Wooden Furniture Industry at the North Coast of Java in Pre and Post Reformation: A Case Study in Jepara Wooden Furniture Centre". Advanced Science Letters Vol. 23, No. 10, 2017 Pp. 9981

Basuki, Sulistyo, 2006. Metode Penelitian. Jakarta: Wedatama Widya sastra- Fakultas Ilmu Pengethauan BUdaya UI.

Bungin, Burhan. 2004. Metodologi Penelitian Kualitatif Aktualisasi Metoddologis ke Arah Ragam Varian Kontemporer. Jakarta: RajaGrafindo Persada.

Fauziah, Fitri Ella, dkk. "Pengaruh Lesunya Industri Mebel Terhadap Keluarga Pengusaha Mebel Wanita Di Jepara (The Effect Of Furniture Industry Sluggish To Family Furniture Women Entrepreneurs In Jepara)". Fokus Ekonomi Vol. 9 No. 2 Desember 2014. Pp. 15- 33 .

FEDEP. Tt. Seni Ukir Kayu Teknik dan Proses. Jepara: FEDEP.

Gustami, SP. 1999. Seni Kerajinan Mebel Ukir Jepara: Kajian Estetik Melalui Pendekatan Multi Disiplin. Yogkarta: Kanisius.

Garraghan, Gilbert J. 1947. A Guide to Historical Method. New York: Fordham University Press.

Gottschalk, Louis. 1975. Mengerti Sejarah. Terjemahan Nugroho Notosusanto. Jakarta:Yayasan Penerbit Universitas Indonesia

Hartojo dan Budiman, Amen. 1982. Kompleks Makam Ratu Kalinyamat Mantingan Jepara Segi-Segi Sejarah dan Arsitektur. Jawa Tengah: Proyek Pengembangan Permuseuman.

Haryadi, Kus. 2016. Langgam Relief Jepara. Jepara: Lembaga Pelestari Seni Ukir, Batik, dan Tenun Jepara.

Hayati, Chusnul, et al., Ratu Kalinyamat: Biografi Tokoh Wanita Abad XVI dari Jepara, Semarang: Pemerintah Kabupaten Jepara dan Pusat Penelitian Sosial Budaya Lemlit Undip bekerjasama dengan Penerbit Jeda (2007).

Herlina, Nina. 2008. Metode Sejarah. Bandung: Satya Historika. 
Kadir, Abdul. 1979. Risalah dan Kumpulna Data tentang Perkembangan Seni Ukir Jepara. Jepara: pemerintah Kabuoaten Daerah Tingkat II Jepara.

Kemendiknas, 2008. Kamus Besar bahasa Indonesia Edisi IV. Jakarta: Gramedia Pustaka Utama.

Marizar, Eddy Supriyatna, 2012. Budaya Tionghoa Dalam Desain Mebel di jepara, Indoensia. Jakarta: Pusat Kajian Budaya Tionghoa Lemlit dan Publiaksi Ilmiah Unversias Tarumanegara.

Maziyah, Alamsyah, Indrahti, 2015. Ornamen Mantingan. Semarang: Museum Ranggawarsita Jawa Tengah.

Priyanto, Hadi. 2018. Ratu Kalinyamat Rainha de Japara. Semarang: Yayasan Kartini Jepara

Priyanto, Hadi, dkk. 2013. Mozaik Seni Ukir Jepara. Semarang: Lembaga Seni Ukir, Batik, dan Tenun Jepara.

Pujianto, dkk.1999. Sejarah dan Perkembangan Seni Ukir Jepara. Jepara: Pemda Dati II Jepara

Saebani, Beni Ahmad. Tt. Metode Penelitian. Bandung: Pustaka Setia.

Singarimbun, Masri dan Sofian Efendi. 1995. Metode Penelitian Survai. Jakarta: LP3ES

Soepratno, 2004. Mengenal Budaya Bangsa Ornamen Ukiran Kayu Tradisional Jawa I Ketrampilan Menggambar dan Mengukir Kayu. Semarang: Effhar dan Dahara Prize.

\section{Daftar Informan}

\begin{tabular}{|c|c|c|c|c|c|}
\hline \multirow[t]{4}{*}{1.} & Nama & : Sukoco & & \multirow{2}{*}{$\begin{array}{l}\text { Nama } \\
\text { Umur }\end{array}$} & : Supardi \\
\hline & Alamat & : Mulyoharjo RT 012/05 & & & : 63 tahun \\
\hline & Umur & : 58 tahun & & Alamat & : Mulyoharjo \\
\hline & Pekejaan & : Pekerja Ukiran Relief & & Pekerjaan & : Pekerja Ukiran Releief \\
\hline 2. & Nama & : Hendriyono & 7. & Nama & : Joko Lakseno \\
\hline & Alamat & : Senenan RT 01/ 02 & & Umur & : 40 tahun \\
\hline & Umur & : 62 tahun & & Alamat & : Senenan \\
\hline & Pekerjaan & : Pekerja Ukiran Relief & & Pekerjaan & : Pekerja Ukiran Releif \\
\hline 3. & Nama & : Partono, & 8. & Nama & : Slamet \\
\hline & Alamat & :Senenan RT 04/02 & & Umur & : 51tahun \\
\hline & Umur & : 49 tahun & & Alamat & : Mulyoharjo \\
\hline & Pekerjaan & : Pekerja Ukiran Relief & & Pekerjaan & : Pekerja Ukiran Relief \\
\hline 4. & Nama & : Dardi & 9. & Nama & : Ngateno \\
\hline & Alamat & : Mulyoharjo RT 01/05 & & Umur & : 46 tahun \\
\hline & Umur & $: 60$ tahun & & Alamat & : Senenan \\
\hline & Pekerjaan & : Pekerja Ukiran Relief & & Pekerjaan & : Pekerja Ukiran Releief \\
\hline 5. & Nama & : Rondi & & & \\
\hline & Alamat & : Mulyoharjo RT $02 / 05$ & & & \\
\hline & Umur & $: 60$ tanun & & & \\
\hline & Pekerjaan & : Pekerja Ukiran Releief & & & \\
\hline
\end{tabular}

